\title{
10. The good, the bad and the faithful: The response by Indian religious groups $^{1}$
}

\section{Jonathon Prasad}

Shortly after lunchtime on 5 December 2006, crowds began to assemble outside Prime Minister Laisenia Qarase's residence on Richards Road, Suva. At first they arrived slowly, a few at a time; but, as the afternoon progressed, numbers rapidly swelled, particularly after the arrival of the Republic of Fiji Military Forces (RFMF). ${ }^{2}$ The crowds were drawn by the news that their government was in the process of being overthrown, and the rumour that their prime minister would shortly be placed under house arrest. ${ }^{3}$ The congregated sang mournful hymns and offered prayers for the nation in both Fijian and English. They rallied in support of democracy and to register their opposition to the military's escalating political involvement over previous weeks. ${ }^{4}$ Some had assembled spontaneously, whilst others, going by the church minibuses parked nearby, had been assisted to come by church ministers. ${ }^{5}$

The elaborate game of cat and mouse that had been played out over the previous days showed Qarase to be skilled in evading the military while operating a 'government on the move' and frustrating all efforts to locate him. ${ }^{6}$ As the game neared its inevitable climax, all that remained between the military and Qarase was a line of the faithful, singing hymns and offering prayers: A moral force separating 'good' from 'evil'. 7 '

The dividing line between good and evil is an important, if relative, one in Fiji. The influence of religion pervades society, with both Qarase's and FLP-leader Chaudhry's religious convictions being as much a part of their appeal to the electorate as their ethnicity and political stance. ${ }^{8}$ The relationship between religion and ethnicity is pronounced. Nearly all ethnic Fijians identify themselves as Christians; the Indian population is predominantly Hindu (76.7 per cent), with smaller groups of Muslim (15.9 per cent) and Christian (6.1 per cent). ${ }^{9}$ For indigenous Fijians, Christianity represents a particular stage of social development, signifying a break with pre-Christian spirituality and cannibalistic practices, and uniting groups previously fragmented by tribal conflict under a common set of values. For the Indians, while religion represents an act of faith, it also provides a tangible link to the history of their settlement. It further transforms them from an isolated community in the Pacific to one historically connected to the grand religious, cultural and linguistic traditions of India. 
Fiji remains a nation polarized by ethnicity, with communal voting exacerbating divisions, and skewing election outcomes. In the days immediately before and after the coup, the battle for the people's hearts and minds focused upon claims by both sides to be the defenders of the rule of law and righteousness. Bainimarama's 'clean-up campaign' was described as a moral crusade to cleanse the nation of corruption and discrimination, which he claimed was endemic under the Qarase government. Qarase, on the other hand, appealed directly to the rule of law, which he argued was directly threatened by the actions of the military. He claimed that the foundations on which society rested were systematically being undermined, with principles of democracy, good governance, the rule of law, and human rights being swept aside. He warned that this would be replaced by dictatorship through the barrel of the gun, which would inevitably lead to injustice, repression and chaos. ${ }^{10}$

Qarase's support base amongst the Assemblies of Christian Churches in Fiji (ACCF) - which includes the dominant and influential Methodist Church claimed that the authority of God passed to man through elected representatives, and that any challenge to this order would directly challenge the authority of God, resulting in Bainimarama 'himself' being 'cleaned up'. 11 This appeal to non-earthly sources of authority was also found in the response of Hindus, through their emphasis on the religious authority of their scriptural system as bound up in the metaphysics of 'dharma'. Dharma is a central concept in Hindu thought. Having no English equivalence, it is notoriously difficult to define but is commonly interpreted as justice, virtue, ethics, duty, truth, goodness and morality; it is regarded as the principle which upholds the moral and physical world. ${ }^{12}$ In Fiji, dharma signifies the duty of each person towards a life of good conduct and the performance of righteous actions. These ideas are bound up in a cosmic jurisprudence, transcending national boundaries and temporal concerns.

\section{The Indian community between 1987 and 2006: A community under siege?}

The position of the Indians in Fiji is a precarious one, with the post-1987 period commonly referred to as a second girmit. ${ }^{13}$ Unable to own land, the sense of insecurity and uncertainty is palpable. Since the mid-1990s, Indian farm leases have expired and many farmers evicted, often without compensation. ${ }^{14}$ It is suggested by some that this is a direct consequence of a nationalist agenda, which has sought to marginalize the Indian position in Fiji. A trip to cane-growing areas tends to support this view, as many previously fertile, productive fields previously tilled by Indian farmers lie idle at a time when the cane industry is struggling to meet its commitment to fill international sugar orders. $^{15}$ 
The population figures are a sobering reminder of the human costs wrought by the coups. The census for 1986 showed Indians constituting 52 per cent of the total population. By 2007 this had declined to 38 per cent. In the 20 years since 1987 scores of thousands of Indians have left Fiji, many of them professionals. ${ }^{16}$ The resulting vacuum has been filled by ethnic Fijians through processes of positive discrimination that have seen Indians being passed over for promotion, or their positions being made redundant. Increased levels of unemployment and underemployment within the Indian community have led to a decline in self esteem amongst many men, and increased domestic violence, marital breakdown and suicide. ${ }^{17}$

In the aftermath of the 1987 and 2000 coups, the Indian community found itself on the receiving end of unprecedented violence:

... [F]or a few weeks there was unprecedented violence, particularly stoning and arson attacks against Indian homes by young Fijian men, sometimes with assaults and robbery. The attacks continued sporadically for a long time, and there were incidents of intimidation and physical abuse by members of the military. ${ }^{18}$

There was also an increase in violent home invasions. The targets were predominantly in the Indian community. In some cases, daughters have been raped in front of their parents, whilst there have been several reported deaths resulting either directly or indirectly from these invasions. ${ }^{19}$

\section{The responses of the Indian community}

\section{Responses to the build-up to the coup}

Whilst some protests were made against the 1987 coups, these were organized by trade unions, rather than coordinated by the various Indian religious groups. Some farmers refused to harvest their cane, but in the long-run they only harmed themselves and their families, as they were not paid. ${ }^{20}$ It is common to hear people express the futility of their situation. Others have resigned themselves to their fate, arguing that the land inevitably belongs to the Fijians as they were there before the Indians. It is possibly for this reason that religion and culture are so important to Indians in Fiji; they are the two things that cannot be taken away from them, and explain why many have a firm belief in their prayers believing their religion will offer them guidance and the capacity to endure whatever calamity befalls them.

The introduction of the Promotion of Reconciliation, Tolerance and Unity (RTU) Bill (2005) and the Qoliqoli Bill and Indigenous Claims Tribunal Bill (2006) has been interpreted as a further attempt to marginalize the Indian community. Qarase had previously claimed that those who went to the Parliament complex in 2000 were answering the Tagi ni Taukei, the 'Cry of the Fijians', and that, 
rather than being intent on troublemaking, they were the victims of a legal system that had failed to recognize customary behaviour. ${ }^{21}$ The RTU Bill took this a step further, by proposing an amnesty for those involved in the 2000 coup. The Qoliqoli Bill had the potential to restrict access of non-Fijians to coastal waters and fishing rights. ${ }^{22}$ Society became polarized, with those in favour of the bills being characterized as the 'Blue Ribbons'; those against, the 'Yellow Ribbons'. The Methodist Church actively supported the bills; in a rare act of solidarity, almost all the 'Yellow Ribbon' Hindu and Muslim groups issued statements condemning the bills in part or in total. Their criticisms focused on the amnesty provision of the RTU Bill, which they felt would promote a coup culture and prove divisive for Fiji society. They questioned whether or not one could legislate for reconciliation, arguing that it was a personal sentiment that had to come from within. A further concern was that it ran contrary to the spirit of democracy.

A Tebbutt Poll commissioned by The Fiji Times, revealed that only 19 per cent of Indians expressed support for the Bill. Despite this, Qarase persisted, and, in a move calculated to close the distance between religions, suggested the restorative justice component of the Bill was in keeping with the noble tradition of forgiveness:

... a principle common to all the great religions practiced in Fiji. This is the golden thread that links them ... Hindu scripture, for instance, regards forgiveness as holy and calls it the highest virtue. ${ }^{23}$

Caught between the Blue and Yellow camps was the Indian division of the Methodist Church. Eventually, the Indian division acceded to the request of the leadership and offered their support, although this was conditional on the Bill leading to real reconciliation. ${ }^{24}$

\section{Post-coup responses}

Writing in The Fiji Times shortly after the 2006 coup, Verenaisi Raicola noted the importance of religion for the people of Fiji:

Fiji is a unique country with many practicing and non-practicing Christians. So when there is a political crisis, unlike other countries where people look to politicians to resolve issues of importance, our people look to the churches for divine interventions. ${ }^{25}$

This echoes Satendra Nandan, a member of the ill-fated Bavadra government of 1987, who argued that religion plays a symbolic as well as functional role for individuals and groups:

During the coups and in their aftermath the myriad, ubiquitous ceremonies became a form of resistance. Hindu holy texts, the Ramayana and the Gita, are both about fighting evil and the final triumph of good. 
There is no doubt that many saw the coups as the banality of ethnic evil, Adharma. ${ }^{26}$

Commentators expected the Indians to respond to the 2006 coup with an ebullient outpouring of support for the military, but the predicted celebrations failed to materialize. There were no tears of joy, no dancing in the streets, no prayers of thanks - for most there was only emptiness, a familiar pang of recognition. For many survivors of previous coups, this was a well-rehearsed drill; they knew how their lives would be disrupted. Many, however, expressed a sense of relief that the protracted build-up, the phoney-war of words in which the military declared there would be no coup, had finally and decisively come to an end. For Indians, there was the further relief that this time they were not the targets. Far from a sense of schadenfreude, daily events were picked over in minute detail; self-appointed commentators around the tanoas in Indian households offered their interpretation and prognosis for the future.

Religion plays a crucial role in the aftermath of traumatic events. It provides a means of interpreting, mapping and coping with uncertainty, with religious leaders offering guidance, leadership and reaffirming community ties. ${ }^{27}$ Public worship allows a community to share their fears and join together in hopes of a positive outcome; it allows devotees to play an active role and provides a sense that one is somehow guiding events, rather than passively observing. When Qarase went to meet with Bainimarama in New Zealand for 11th hour talks in a bid to avert the 2006 coup, religious groups of all denominations called on the nation to pray for their successful outcome.

\section{The perceived impact on poverty}

One of the immediate concerns voiced by religious groups was how the poor would be affected by the coup. Sections of the Indian community are amongst the poorest groups in Fiji, with farmers facing increased hardship since land leases began to expire, and a raft of welfare policies having benefited the indigenous community at the expense of the Indians. ${ }^{28}$

Sections of the international donor community responded to the coup by discontinuing aid, imposing trade and travel restrictions and limiting international scholarships. ${ }^{29}$ This came at a time when preferential access to the EU markets for African, Caribbean and Pacific nations (ACP nations) was being phased out because it breached international trade laws. The threat of the removal of the financial package to aid transition was dangled before the interim government unless it provided a 'roadmap' back to democracy. The potential loss of the transitional aid package led to concerns that the lives of those living in poverty or on the cusp of it would be negatively affected.

Poverty is an area that religious groups feel comfortable discussing, as it allows them to comment indirectly on political issues. In the aftermath of the 2006 coup, 
the Arya Pratinidhi Sabha of Fiji (APS/Fiji) urged a dialogue between the military and government in order to avoid further hardships affecting the farmers. They suggested that religious organizations had an important role to play in the dialogue between the two sides - identifying the source of the problem as a lack of wisdom and of a sense of common good for all. ${ }^{30}$ The then president of the Shree Sanatan Dharm Pratinidhi Sabha (SSDPS), Surendra Kumar, stated that those hardest hit by the coup would be those already living under the poverty line. ${ }^{31}$ The Sangam and SSDPS asked their sister organizations in Australia and New Zealand to make representations to the governments of both countries calling for the lifting of sanctions. ${ }^{32}$

In the aftermath of the coup, the Indian community and their representative organizations, fearful of reprisals, became sensitive to suggestions that they were implicated, and immediately sought to quash such claims. When FemLINKpacific coordinator Sharon Bhagwan-Rolls suggested that the Indian community was receptive towards the overthrow of the Qarase government, she was condemned by Swani Maharaj, former president of the SSDPS Lautoka:

We are really disgusted with the statement and we want to know which segments of the Indian community she is trying to talk about and which ones she represents. Since past coups, someone always has to blame the Indo-Fijians $\ldots$ if there is anyone who wanted to talk about the Indo-Fijian community, it ought to be someone like Labour leader Mahendra Chaudhry who had the support of the people and leaders of the various religious groups in the country ... The commander of the military has told the public that they need cooperation ... the Indian community is cooperating and wants a recovery to democratic rule ... Although the military takeover is illegal, it did not abrogate the Constitution which is vital in keeping the multi cultural society of this country. ${ }^{33}$

The difficulty faced by Indian religious groups was how to respond. One of the stated aims of the coup was to end the discrimination against the Indian community. Despite this, religious groups could not be seen to condone the military's actions, which represented an adharmic act. The largest Indian organization in Fiji - the SSDPS, which claims to represent over 200,000 Hindus - negotiated this difficulty by distancing the organization from the 'overthrow'. However, given the reality of the situation, it accepted that the military should be allowed to complete its task, especially if it related to claims of corruption. When Bainimarama issued a warning to NGOs not to speak out against the military, Surendra Kumar urged the public to remain silent and allow the military to carry out its task, saying:

[W] should not cause hindrance to their work because its [sic] members of the public who have to face the consequence of any wrong comment 
that they make ... the best thing for the entire nation to do is let them do their task while we wait and pray for normalcy in the country. ${ }^{34}$

\section{The response of the SSDPS}

The SSDPS purported to adopt a neutral stance during the early days of the coup, stating that they were not in a position to judge either Qarase or Bainimarama. ${ }^{35}$ However, the SSDPS statement appears to legitimize the actions of the military; it refers to it as performing 'work' and suggests that statements in opposition to it were 'wrong'.

From a Hindu perspective the coup occupies a grey area; Hindu mythology is filled with stories of coups and counter-coups in a quest for power and supremacy. Some argued that pursuance of dharma legitimized the coup. In the case of the 2006 coup, it may be argued that the proposed RTU and Qoliqoli bills could potentially have inflicted harm on the Indian community. Because of this, an act that sought to lessen this harm - such as the overthrowing of a democratically elected government - would be morally and 'dharmically' legitimate. ${ }^{36}$

\section{The response of the TISI Sangam}

By contrast, the South Indian Hindu organisation, the Then India Sanmarga Ikya Sangam (TISI Sangam), has consistently condemned the coup, speaking out in defence of democracy. Dorsami Naidu is simultaneously the head of the TISI Sangam, a former president of the National Federation Party and a prominent Nadi-based lawyer. He spoke out against the RTU Bill - arranging demonstrations and a petition against it. After the coup the Sangam stated:

The illegal and unlawful takeover of a democratically elected government will never be condoned. We all may not agree with the policies of the government but that does not give anyone the right to do what the military has. ${ }^{37}$

The Sangam, in common with the SSDPS and APS, restricted its comments to social issues, choosing not to condone or condemn the action of the military. Rather, they chose to comment directly on the social consequences of the coup, on poverty, the increased sense of safety felt by the population due to the presence of road blocks, and the decline in temple desecrations. ${ }^{38}$

The Sangam was directly affected by the coup. As one of the larger Indian religious organizations, it had planned to expand its educational portfolio by developing a nursing school and a vocational training centre. The nursing school was established with support from the Asian Development Bank (ADB). An additional $\mathrm{F} \$ 3$ million was to be provided by the ADB for the establishment of the vocational school. However, before funds were released, the coup occurred. The costs were not inconsiderable: Sangam had already purchased the site, 
employed an architect and invested time in the project. The project would have created up to 200 jobs for builders and teachers, and opportunities for the school's graduates. The Sangam is unclear as to whether or not funding will be reinstated, and are wary of future dependence on international donor funding. It is moving towards financial independence, seeking funds from amongst its members and through the diversification of its financial arrangements. ${ }^{39}$

In his capacity as a lawyer, Naidu defended Angie Heffernan, chief executive of the Pacific Centre for Public Integrity, an outspoken human rights activist, and one of the founders of the Lami 'democracy shrine' established in protest at the coup. The case questioned the legitimacy of the interim government. In accepting the case, Naidu positioned himself in opposition to the military. Naidu had previously been president of the National Federation Party (NFP), the preferred party of the Indian community until the arrival of the FLP. Significantly, prior to the election, Naidu had made an uneasy alliance with the SDL, offering to become a coalition partner in the event of a hung parliament. This support was contingent upon the removal of the amnesty provision from the RTU Bill. It would, of course, have placed the NFP back in government.

Naidu's opposition to the coup was based upon his belief that it was the illegal overthrow of a democratically elected government, an action that he regards as morally wrong and therefore adharmic. When asked about whether or not he found it difficult to separate his different societal roles, he responded that his personal views mirrored those of the Sangam and the NFP during his time leading those respective organizations.

\section{The response of the APS/Fiji}

The APS/Fiji took the position of observer, choosing to neither condemn nor condone the coup, as they believed that:

If the end result is positive and brings benefit to all, then it can be justified as something right, dharmic. However, if it takes the situation in Fiji to a stage which is worse than December $5^{\text {th }}$, then it is wrong adharmic. We cannot judge at this stage, only time will tell. ${ }^{40}$

Despite this, APS/Fiji was disappointed that all democratic avenues were not explored in order to ensure a peaceful resolution with the minimum of disruption to the nation. They pointed to dialogue as the most transparent way of solving disputes in a democratic society, and argued that, regardless of future outcomes, the will of the people must prevail, and must be freely arrived at without outside interference or coercion. The APS/Fiji discussed the coup during its convention and gave a briefing to delegates - but it did not suggest a position to be adopted by followers because it believed it wrong for an organization to impose its will upon its members as this removes people's freedom to decide. 


\section{The response of the Indian division of the Methodist Church}

The coup further strained relations within the Methodist Church. Whilst the leaders of the church condemned the military, members of the Indian division were divided, with many supporting the military's anti-corruption stance. Some members of the Indian division began openly questioning their leadership as to why it hadn't condemned the 1987 and 2000 coups. This placed the Indian division in a difficult situation, as they were aware that the stance of the parent body would potentially lead to a loss of confidence in the organization amongst its Indian supporters. 41

The increased military presence on the streets received support from all communities, as it provided a sense of security, with many in the Indo-Fijian community hoping it would become a permanent feature. The addition of military checkpoints and the promise that crime would be swiftly dealt with meant that the Christmas period was the first when the people of Fiji did not have to worry about crime. This found particular support amongst the Indian community, which had previously been the target of break-ins and attacks. During this period there were no reported temple attacks. Surendra Kumar said that:

... they [the Indians] were fed up of daily break-ins by indigenous Fijian youths ... we hope that the military maintains this peace and harmony in the country and restores democracy. We know that the overthrow of the democratically elected government is illegal and unconstitutional and there are other means of solving this problem but it is a fact that our Hindu brothers were victims of daily break-ins. ${ }^{42}$

The sense of security was acknowledged by Nasinu Town Council Mayor Rajeshwar Kumar, who, along with other councillors (the majority of whom were Indian), prepared lunch for 180 soldiers stationed along the Suva-Nausori corridor to show their appreciation and gratitude for the efforts made by soldiers during the Christmas holidays to bring safety and stability to the area, allowing people to walk freely on the streets and feel safer in their homes. ${ }^{43}$

\section{7 - Mahendra Chaudhry: The return of the king?}

The 2006 election saw a sizable increase in the number of Indian votes cast for the FLP at the expense of the NFP. ${ }^{44}$ Many saw Chaudhry as the personification of the FLP; by others he was regarded as an avatar of King Rama, the heroic-mythic figure of the Hindu Epic, the Rāmcaritmānas.

The metaphor of Chaudhry as the inheritor of Rama's legacy draws upon the example of the hardship and suffering Rama endured during his enforced exile from his kingdom, during which time he wandered in the wilderness, being tested through various trials. Despite these challenges he was able to exhibit critical judgement and maintain his sense of righteousness and morality. The 
moral underpinning of the text is that Rama is the embodiment of dharma, and that a person who adopts the path of righteousness, upholding dharma, is destined to triumph over ignorance and evil. ${ }^{45}$

Chaudhry, as a shrewd and skilled politician, is most likely aware of this comparison, and is wont to use it to his advantage. During his 2002 Diwali message he reminded the Hindu community of the timeless appeal of the text, with Rama as the embodiment of renunciation, self-discipline and duty. He extolled the virtues of being responsive, a good ruler, sensitive to the needs of his people.

We may not have the ancient demons to fight against today. But there are the modern day ones, heaping injustice on society. There are other unfortunate people among us, whom we should not forget in the enjoyment of our own riches.

He highlighted the importance of acting in accordance with dharma to fight injustice, and defend rights, and personalized this by reflecting on the sacrifices he had made for the benefit of the community by means of his struggle to obtain a position in the post-2001 election cabinet:

How many times have I been advised to accept the position of Leader of the Opposition and to forget about our right to be included in the Cabinet and to form part of the government? It would be the easy way out. I would be the Leader of Opposition, pick up a hefty salary, have a car and driver at my disposal and be consulted on all key decisions and appointments. ${ }^{46}$

In the aftermath of the 2000 coup, Chaudhry was heralded by the BBC as '[A] figurehead for the aspirations of Fiji's Indian community, a crusader for democracy and the rule of law' due to his act of forgiveness towards George Speight. ${ }^{47}$

His immediate condemnation of the 2006 coup as an illegal act and a sad day for Fiji, appeared consistent with his previous statements. The statement declared that neither Chaudhry nor the FLP supported:

... the military takeover of the democratically elected Qarase government. We just can't get out of the coup culture. We can't support the takeover and we hope the commander will quickly restore democracy to the country ... the fourth coup will escalate poverty, unemployment and further cripple the economy. The three previous coups have taken Fiji back 20 years.

Chaudhry declared that he would not be part of the interim government, and vowed to uphold democracy and the rule of law. ${ }^{48}$ However, in January 2007, Chaudhry reversed this position by accepting the portfolio of the minister of 
finance in the interim government. He claimed as justification that he was acting under the orders of President Ratu Josefa Iloilo.

The decision by Chaudhry to join the interim government was viewed with skepticism by some sections of the Indian community. Having previously established himself as defending righteousness, calling for the reinstatement of a deposed government after 2000 , he had been lauded by the community as a just leader. However, his decision to join the interim government divided the community as to whether or not he had been seduced by the prospect of power backed by the might of the military. Around tanoas across Fiji, debates took place, with some going as far as to suggest that Chaudhry was the author of the coup.

Chaudhry's presence as a member of the interim government made it more acceptable for the Indian community to support it. Some cited the Bhagavad-Gita, casting him into the role of Lord Krishna, bringing righteousness to bear:

Whenever virtue declines and unrighteousness rises, I manifest Myself as an embodied being. To protect the Saints and Sages, to destroy the evil-doers and to establish Dharma (righteousness), I am born from age to age. ${ }^{49}$

For these people, Chaudhry's return to government was the circle complete, with him being returned to the position he had occupied before being ousted as part of the Bavadra government in the coup of 1987. It was dharma in action, with righteousness restored, and the proper order of the universe settled. Others, however, thought a different circle had been transgressed, that of the 'Laxman-Rekha' (circle of Laxman). In the mythology of the Rāmcaritmānas, this was the circle that Laxman, half-brother of Rama, drew on the ground in order to prevent any harm coming to Sita whilst they were in exile. It was a circle of safety, security and comfort separating Sita from the dangers and uncertainty of the world beyond - a dividing line between good and evil. ${ }^{50}$ It is claimed that Chaudhry has taken the Indian community beyond the protective-circle, by performing an adharmic act. Comments made by farmers in rural Vanua Levu echoed these sentiments:

After the 1987 and 2000 coups, we [the Indians] were regarded as the victims of people that did not respect democracy, human rights or cultural traditions - we were the principled people. However, we can no longer claim this, and we no longer have the international communities support, sympathy and respect. We have now become the aggressors. ${ }^{51}$

Critics of Chaudhry have played upon the idea of causation, prevalent in Hindu thought and suggesting that the hardships and natural disasters which have befallen Fiji since the coup - rising food and fuel prices, increased unemployment, water shortages, the imposition of sanctions, various cyclones - were a 
consequence of his actions. This was extended to suggest that Chaudhry's chickens had come home to roost when, in late February 2008, he found himself accused of tax evasion in Fiji after the discovery of five separate bank accounts registered to him in Australia and containing a total of AU\$1.6 million. Throughout, he denied any wrongdoing, claiming that the money had been raised in India after the 2000 coup to help him and his family resettle in Australia if needed. ${ }^{52}$ This coincided with Bainimarama's controversial decision to install himself as the head of the GCC, and a much-vaunted report into the land issue authored by Dr Krishnamurthi - suggesting that land that had previously been reserved, be de-reserved - was rejected by the NLTB. The Indian community became unsettled, believing that the consequences of adharma were being repaid. Hushed critical voices began talking in terms of karma, with former allies Bijay Prasad and Krishna Datt urging Chaudhry to resign because the FLP was being damaged by its association with the interim government. ${ }^{53}$ Another former colleague, Tupeni Baba, looked forward to a post-Chaudhry era, saying, 'Fiji's politics without him will be cleaner, less racially polarised and congenial' . 44

Chaudhry, however, remained steadfast, and was later cleared of any wrong-doing by an 'independent' inquiry, established by the interim government. The media questioned the independence of the inquiry team, focusing on the facts that interim Attorney-General Aiyaz Sayed-Khaiyum had previously worked for Minter Ellison - the law firm from which an Australian-based member of the inquiry team was drawn - and that his aunt, Dr Nur-Bano Ali, ran the franchise for BDO Kendall in Fiji, the accountancy firm from which another Australia based-member of the team was drawn. Questions were also raised about the secretive way in which the inquiry team was established, as its existence was only made public the day before it submitted its report. When the media sought a response from the two Australian-based experts, they were told that they had no comments to make; the two left the country the day the report was delivered - a bank holiday. The Attorney-General, clearly angered by the media's investigations, felt that they had a 'personal' agenda against Chaudhry, with critics grasping at anything to create doubt in the minds of the public. ${ }^{55}$ The event took a toll on Chaudhry's reputation ${ }^{56}$ and led him to respond to claims that he had lost the support of the Indian community saying 'The Indian community has never doubted my integrity...I have never had any doubts about my community, the Indian community being behind $\mathrm{me}^{\prime} .{ }^{57}$

\section{The National Council for Building a Better Fiji: Dharmic or adharmic?}

Since the coups of 1987, Indian religious groups have expressed concern that they were not consulted or involved in the post-coup reconstruction process. ${ }^{58}$ They felt that, as representatives of large sections of the population, including 
the business community, their opinion should have been solicited as to Fiji's future direction. It is commonly felt that, had their opinion been sought, they may have been able to allay some of the fears that existed on both sides, many of which continue to simmer beneath the surface. This would have helped heal the divisions between communities, leading to a greater understanding and possibly preventing further coups. ${ }^{59}$

A People's Charter, prepared under the auspices of the National Council for Building a Better Fiji (NCBBF), is the platform the interim government is pursuing to 'heal the nation' and plan its development. The interim government is seeking to rebuild trust in the political process and increase the sense that all are stakeholders. In doing so it hopes that the Indian community will feel as much a part of the decision-making process as other communities:

The proposed People's Charter is a national cause, which will lay a foundation for change, peace, political stability and prosperity in the country. It will seek to bring about change in attitude and provide ways to deal with our socially and culturally-fragmented society and find ways to build a better Fiji. ${ }^{60}$

The nature of the charter has changed over time. When it was introduced, it was floated as a consultation exercise; however, over time, it has morphed into the political program for the next government. ${ }^{61}$ Through a process of widespread consultation it is envisioned that people will take ownership of the charter; working to ensure its success. There has, however, been a mixed reaction to it within the Indian community, with the process highlighting and exacerbating differences between groups. However, a positive outcome has been that Indian religious groups feel they have found the voice they lost after 1987, and feel safe speaking out whilst engaging in public debate.

The invitation to join the NCBBF was extended by President Ratu Josefa Iloilo to key stakeholders in society, with major religious groups of all faiths being well represented. It was intended that the NCBBF would be filled by a representative cross-section of those organizations currently working with different communities in Fiji. While some of the invited groups turned down the invitation, others were happy to accept - which tells much about the relationships between groups and their internal politics. It also develops an interesting dynamic, highlighting historical and theological differences between groups, and the extent to which the Indian community is fragmented. ${ }^{62}$ These dynamics may be seen as operating across a number of axes: Sanatan v Arya; TISI Sangam v Andhra Sangam; and Fiji Muslim League v Ahmadiyya. The internal divisions within the Methodist Church may be crudely analysed along the racial category Indian v Fijian. 


\section{Sanatan v Arya}

The decision by both the SSDPS and APS/Fiji to accept seats on the NCBBF can be seen as a continuation of the struggle for influence in the Indian community dating back to the 1920s and 1930s. ${ }^{63}$ At that time, there were bitter debates, led by spiritual leaders, in relation to fundamental theological differences. Sanatani Hindus recognize the scriptural authority of the Rāmcaritmānas and Mahabharata, in addition to practicing deity worship. By contrast, the Arya Samaj rejects the epic tradition and idol worship, regarding it as a lower form of devotion; they emphasise the Vedas, a more philosophical set of texts. This leads them to reinterpret festivals such as Diwali in secular terms - making it similar to a harvest festival. There are also fundamental differences in their respective stances on child marriage, widow re-marriage, and the sexual conduct of prophets and gods. These debates opened fissures within the Indian community, which continue into the present, although in a less hostile mode. Sanatanis make up the majority of Hindus in Fiji, numbering approximately 200,000 , and come from a wide cross-section of the community - from farmers through to affluent business people. The support base for the Arya Samaj is significantly smaller - approximately 50,000 - although their membership attracts a larger number of professionals. In a sense, neither the SSDPS nor APS/Fiji had a choice as to whether or not to join the NCBBF - for if one hadn't, the other would have become the official spokespeople for the Hindu community.

Both leaders joined the NCBBF at its initial meeting in January 2008. Kamlesh Arya joined as head of the APS/Fiji, mandated to do so after a lengthy consultation process with key advisors, lawyers, the APS/Fiji National Executive and the national convention. ${ }^{64}$ For Arya, the NCBBF may provide 'sufficient leverage' to bring together communities which have been kept apart. Its members argue that their participation is one of the best ways to move the country forward. ${ }^{65}$ In accepting the invitation, the APS/Fiji were mindful that the key values the charter invitation referred to - good governance, friendship, transparent action, tolerance, communal harmony, respect and a level platform - were values shared by Vedic philosophy. Therefore, they see the APS/Fiji and NCBBF as sharing a set of common values, which ultimately promotes dharma. ${ }^{66}$ However, critics have pointed to self-interest in securing continued government support for the APS/Fiji-founded University of Fiji as a more likely explanation for their involvement. ${ }^{67}$ Immediately prior to the 2006 election, Kamlesh Arya, a former senior FLP parliamentarian, resigned from the party after a well-publicized dispute with Chaudhry over his style and direction of leadership. ${ }^{68}$ Some cited his decision to 'jump ship' as being influenced by concerns for the fledgling University of Fiji, which required government support for the granting of its charter and funding. At that time, then Prime Minister Qarase was invited to make an address at the University's dedication ceremony. 
In doing so, he spoke of the shared vision of both the government and APS/Fiji for the role of education in the development of Fiji. This closeness was short-lived; in the aftermath of the 2006 coup, Arya has spoken out against the disruption and uncertainty caused by the coup, but, significantly, has not pushed for Qarase's reinstatement. 'Jumping ship' once again, the APS/Fiji moved towards the interim government, extending an invitation to Bainimarama to address their annual convention. The theme of the convention was 'Striving For a Better Fiji', which Bainimarama felt was in keeping with his government's vision for the future. He also congratulated the APS/Fiji on the role they continued to play in the education sector, regarding them as a valued partner of the government of Fiji, and he confirmed the interim government's continued commitment to the University of Fiji, saying:

Today is a good day for us to look back on the journey of the Arya Samaj and reflect on the new directions that will enhance the influence and relevance of the Arya Prathinidhi Sabha in the future. ${ }^{69}$

Whilst the SSDPS has consistently condemned the events of December 2006, its leaders justify their decision to join the NCBBF as indicative of their desire to help move Fiji forward. They argue that, as representatives of 73 per cent of the total Indian population, they have a duty to speak for the interests of their members. In doing so, they are able to relay to a national forum the plight of the Indian community. Aware of their critics, they maintain that their participation should not be seen as support for the interim government, but as providing a voice that has been missing from previous post-coup reconstructions. Further, they do not see their participation as being an adharmic act, and point to their scriptures as filled with examples of such conduct. In the Rāmcaritmannas, Rama was the king's preferred successor, but was forced into exile after one of the king's wives, who preferred the throne for her son, forced the king to crown him instead. Similarly, they argue that the basis of the Mahabharata is the quest for power and is filled with examples of statecraft and the usurpation of power.

Dewan Maharaj was elected the SSDPS president in March 2007, and has sought to stamp his authority on the organization by making intra-faith and interfaith dialogue one of its key priorities. This he regards as important because it will promote cultural understanding, and comes at a time when the SSDPS is facing a crisis of internal division due to the erosion of centralized organizational authority over the previous 40 years. During the 2008 SSDPS national convention, Maharaj claimed that 95 per cent of his members supported the NCBBF process, a statement he was later forced to qualify, recognizing that there were differing views within the organization. ${ }^{70}$ Some have questioned the extent to which the membership was consulted prior to him making such a claim. ${ }^{71}$ During the convention, heated exchanges about the decision to join took place between members and the executive. Questions were also asked of Maharaj's personal 
ambitions, with speculation being raised that he was using the charter as a personal platform to launch his own political career, a claim he strongly denied. The dissenting voices were dismissed as political troublemakers standing in the way of progress, linked to the NFP. Maharaj pointed to the invitation to the convention of Ratu Joni Madraiwiwi, the former Vice-President of Fiji, deposed after the coup, and an outspoken critic of the regime, as evidence that they were engaging in debate over the issue, rather than being beholden to the military. Madraiwiwi, as guest of honour, delivered a speech that recognized the charter as worthy in principle, but with limited validity unless all ethnic groups agreed to participate in significant numbers. He also attacked the interim government for deporting newspaper publishers, for the increased militarization of the public service and for use of the Public Order Act to stifle debate, all of which sit uneasily with the SSDPS' ${ }^{\prime}$ commitment to dharmic principles. ${ }^{72}$

Questions have also been raised about lack of transparency: Maharaj's business interest, a printing company, obtained the contract to print NCBBF literature. ${ }^{73}$ Maharaj, for his part, has not commented on this issue.

At the 2008 SSDPS annual convention, copies of a consultation document for the NCBBF were distributed in both English and Hindi. Amongst those assembled, opinion was divided as to whether the convention was the correct forum for such material. Some argued that such materials had no place in a religious event, whilst others argued that it was a legitimate site due to the concentration of Indians passing through the convention ground over the weekend.

\section{TISI Sangam v Andhra Sangam}

The arrival in Fiji of the 'South Indians', almost a quarter of a century after the 'North Indians' meant that the former found themselves in a social system that had already been established. The lingua franca on the plantations was a derivative of northern dialects, as were the culture and customs practiced; the colonial administration was used to dealing with the North Indians. The later arrival of the South Indians placed them at a disadvantage, leaving them open to victimization and discrimination based upon their physical appearance, language, culture, the way in which they practiced their religion, their cuisine and mode of dress. In addition to this, it was claimed that they were more susceptible to depression and less hardy compared with their North Indian colleagues when it came to work. ${ }^{74}$ South Indians were drawn from areas with distinct linguistic traditions: Tamil, Telegu, Malayalam and Kanada, although the majority were Tamil speakers. They were shunned by the North Indians and were excluded from participating in their social and religious functions. It was several years before they were integrated into the 'Indian' community. To secure themselves against this victimization, they established, in 1926, the TISI Sangam. The intention was for the organization to be a representative body for all peoples of South Indian origin, regardless of their ethnic or religious background. Over 
time, divisions occurred as Telegu speakers began to feel that the Sangam was promoting Tamil language and culture at the expense of other languages, especially that of Telegu speakers. This led to the establishment of the Dakshina India Andhra Sangam in 1941, which sought to preserve Telegu language and culture. Since then, uneasiness has existed between the two rival organizations. The Sangam, estimates its membership to be 30,000, and it is actively engaged in cultural preservation, promoting the Tamil language, Hindu rituals and prayers -including an active fire-walking program. Many of its senior priests are either from India or have trained there. It has invested in all levels of education, including the tertiary sector, with a nursing school in Vanua Levu. Its supporters come from all backgrounds, but include a number of prominent businessmen and professionals who readily offer financial assistance. By contrast, the Andhra Sangam has a much smaller membership - between 2,000 and 5,000 - with some Telugu speakers choosing to join the Sangam. Unlike the Sangam, which has a national reach, the AS is much more localized to the West, having three temples located in the area around $\mathrm{Ba}$, six schools and two colleges, located in the West.

The decision by the Sangam not to join the NCBBF was taken after consultation with its executive committee. The committee decided to continue with the stance they had taken in the aftermath of the 1987 and 2000 coups, namely to recognize the interim government as governing only by force, in the same way that the Rabuka governments had. They argue that they are primarily a cultural organization, and their required apolitical stance would be compromised by joining the NCBBF, which they view as a political initiative. The head of the Technical and Support Secretariat to the NCBBF, John Samy, claimed that the Sangam had failed to understand the purpose and function of the charter, suggesting that their position was most likely the outcome of preconceived ideas rather than facts. He added that he hoped the decision was based on ignorance rather than politics. Samy further argues that, as the charter is a national initiative rather than a political one, the Sangam's integrity would remain intact as the opinions of all stakeholders in society are being sought rather than those of specific sections. $^{75}$

This has allowed the Andhra Sangam to become the de facto national spokes-group for those of South Indian origin, effectively raising their national status and profile. Their leader, Vinod Naidu, does not share the concerns of Dorsami Naidu; he suggested that the AS has a role to play in moving the country forward. ${ }^{76}$ It may, however, be much easier for the AS to join the NCBBF as they have historically rejected the NFP due to the role played by the future leader of the NFP, A D Patel, as legal advisor to the Sangam during the AS/Sangam split. In recent years they have given their support to the FLP. Vinod Naidu, as leader of the AS, praised the FLP's 2006 manifesto, as he felt it was favourable for all the people in the country. He went so far as to say that he felt that it was the best party for Fiji. ${ }^{77}$ Beyond this, they have not issued any statements, 
choosing instead to become familiar with the charter process before offering further comments.

\section{Fiji Muslim League v Ahmadiyya}

The Muslim community has historically sought separate political representation citing a distinct linguistic, religious and cultural heritage from the Hindu community. These calls have largely come from the Fiji Muslim League (FML), which represents the more numerous Sunni community - the non-mainstream Ahmadiyya Muslims represent a smaller section of the community. It is believed that the formation of the FML was partly inspired by the perceived need to prevent the Sunni Muslim community being overtaken by that of the Ahmadiyya, a missionary sect which arrived in the 1920s.

In the aftermath of the 2006 coup, many Muslims feared that it would be regarded as having been instigated - or at least supported - by the Muslim community, due to the fact that several prominent Muslims occupy key positions within the interim government. Aiyaz Sayed-Khaiyum is the prominent interim Attorney-General; Colonel Mohammed Aziz is a senior member of the military and its legal advisor; and the Fiji Human Rights Commission, under the guidance of Shaista Shameem, has been criticized for not being more outspoken on human rights issues, and for issuing a controversial report in the aftermath of the coup, which effectively vindicated the military of any wrong-doing. ${ }^{78}$ Other prominent Muslims include the High Court judge, Nazhat Shameem, and the chair of the electoral commission, Dr Sahu Khan. This has led the FML to maintain a low profile and issue very few statements.

Members of the interim government were critical of organizations representing the Muslim community. Aiyaz Sayed-Khaiyum spoke out against the FML and its administration over the stance it took on the issue of constitutional review, and their demand for separate political representation. He argued that the FML did not have the mandate to speak on behalf of the Muslims living in Fiji. ${ }^{79}$ However, he was present at the FML-organized celebrations for the birthday of prophet Mohammed, as was Ballu Khan - the controversial businessman who stood accused, with others, of a plot to assassinate Bainimarama and other members of the interim government. At the same gathering, the president of the FML, Hafiz Ud Dean Khan, publicly declined President Iloilo's invitation to join the NCBBF. He reasoned that, since its inception in 1972, the League had remained non-political, choosing to remain a 'silent observer, promoting only its core activities in social, religious and educational areas for the benefit of its members' ${ }^{80}$ This stance did not preclude individual members and members of the executive from freely participating in political activities in their personal capacity. Critics of this position argue that the FML was founded as a political organization, pointing to the inclusion of the term 'political' under the organization's objectives in the original Urdu version of the FML constitution. 
The same critics point out that the FML is already a politicized body, as evidenced by several senators having been drawn from the membership of the FML. ${ }^{81}$

After the FML declined the invitation to join the NCBBF, the invitation was extended to the Ahmadiyyas. It had previously been courted by the interim government, as evidenced by the attendance of Parmesh Chand, the interim prime minister's permanent secretary, as guest of honour of the Ahmadiyya at the birthday celebrations of the Prophet Mohammed. In his speech, Chand spoke of the role of the Muslim community as a valuable partner in building a better Fiji $^{82}$ and urged Muslims to do more in moving the country forward. ${ }^{83}$ In accepting the invitation, they were brought into the mainstream, raising their public profile in the same way that the AS did. In doing so they became the representatives of the Muslim community, articulating the Muslim community's concerns and perspective on national issues as diverse as social justice, the role of religion in society, and national identity.

Conscious of the FML's stance on the politicization of the organization, they accepted the invitation after consultation with the Caliph, who gave his permission for the Ahmadiyya's to join. ${ }^{84}$ The Ahmadiyya did not see its position being compromised as long as the NCBBF remained an autonomous and an apolitical entity. The vice-president of the Ahmadiyya Muslim Jama'at, Tahir Munshi, felt that participation in the NCBBF could help move Fiji forward, noting that Fiji had the potential to become the 'Singapore of the Pacific':

It is the responsibility of those holding positions of responsibility to participate for the love of the country ... we cannot see the country declining and if our ideas, however small they may be, if they are good ideas and they get implemented and help the country move forward ... In our Islamic theology love for the country is part of our faith. So wherever we live, we love the country and that's whenever we are asked we are ready to come in. ${ }^{85}$

\section{The Indian division of the Methodist Church}

The issue of the charter brought the internal conflict within the Methodist Church into the public domain. The standing committee of the church declined the invitation to join the NCBBF - however, the Indian division took a contrary position, seeing it as a useful forum through which they would be able to represent the views of their community. It found the standing committee's position to be short-sighted as, by remaining outside the process, they would not be able to help move the country forward. Publicly, members of the Indian division have spoken positively about the charter process to the media, recognizing that one needs to be inside in order to effect change. Members of the Indian division have expressed a desire to informally contribute to the NCBBF process. They rationalize their position on the basis of the idea of brotherly love, 
arguing, 'it is best to forget about differences, with all joining hands, looking to the future' ${ }^{86}$ This position is also partly dictated by self-interest, as its members are conscious that the military views the Methodist Church as a threat, as it represents a strong moral force - and if the Church constantly opposes the military, the military will take a hardened stance against them. The split within the Methodist Church has been largely along racial lines, with the Indian division being a moderate voice urging cooperation in the best interest of the nation. They see their position as being founded on Christian principles rather than exclusively racial self-interest.

\section{The impact of the NCBBF on religious groups}

The interim government clearly had a preference when it came to recruitment of religious groups to the NCBBF. It initially approached the larger national religious groups - some accepted, others declined. When first-preference groups declined, they were replaced by second-preference groups; this has allowed several minority groups to enter the mainstream decision-making process. These groups bring a different perspective and set of issues. However, the inclusion of some groups and not others raises the question of how representative of the wider Indian community the included groups are, and whether or not the Indian community as a whole will be supportive of the charter once it is finalized.

The decision by the FML and Sangam not to play a role in the charter process is unlikely to damage the reputation of those organizations as the national spokes-groups of their respective communities. By not participating, they maintain their organizational integrity; at the same time they shield themselves from any future criticism should the process fail to deliver on its stated aims. The worry for smaller groups is that if the charter becomes politicized - or, as some have claimed, it becomes the manifesto for a new political party - their participation in a taxpayer-funded project leaves them exposed to criticism and further marginalization. This would prove devastating as they don't have the political experience of larger organizations nor the extensive support base of these groups to cushion the impact.

\section{Conclusion}

Out of the tragedy that was 5 December 2006, a ray of hope has shone brightly. Indian groups are, for the first time, publicly commenting on the coup and debating the future trajectory of Fiji - this was unthinkable after the coups of 1987 and 2000, and reflects an increased sense of confidence that they are true stakeholders, with legitimate voices that will be taken seriously. These voices reflect a variety of positions and highlight the differences between groups, but they have had the effect of capturing public imagination in such a way that the wider Indian community feel reconnected to the political process, with people regularly debating the issues in homes and workplaces across the nation. At the 
same time, the continued growth of internet technology has extended the debate beyond the shores of Fiji, with, in what must be another first, the debate becoming a global one - extending to Indo-Fijians living in America, Australia and elsewhere, to those serving in the British army in Europe and elsewhere, and to nurses trained in Fiji, but working in other parts of the Pacific. It has become a truly global dialogue.

The coup itself divided opinion in Fiji. For the most part, the Indian community was saddened and stunned rather than supportive of yet another political upheaval. Despite being the silent victims of anti-Indian aggression for many years, they did not rejoice. Many mourned the loss of the fragile multiparty cabinet, which some believed would have presented the best hope for Fiji since independence. At the same time, many are pragmatic in looking to the future, recognizing that the current political reality is a military one and awaiting the transition that the interim government will effect. Initially, they were heartened by the added sense of security they felt - a result of the military checkpoints stationed around Fiji. However, now that the dust has settled, many are still waiting for the promised proof of large-scale corruption implicating the Qarase government; all they have witnessed so far has been Mahendra Chaudhry's tax irregularities. At the same time, global increases in the cost of food items such as rice, flour and fuel, as well as freak weather conditions that have led to cyclones and flooding have been characterized by some as examples of what happens when one challenges the dharmic order of the universe.

While many within the Indian community welcome the idea of a 'People's Charter', few truly understand its purpose or the legal status it will occupy. One of the coups stated aims - to restore rights previously lost to the Indian community over the past 20 years - has not been enough to convince them that Fiji is a country worth committing to; it looks likely that they will continue to migrate in large numbers as they no longer feel that Fiji is a viable place in which to raise their families or invest. For many, the prognosis looks bleak, with a future filled with temple desecrations, home invasions and assaults on individuals. Some question what would happen if a future government takes a position opposed to that of the military - would it lead to another coup, would Fiji then be firmly entrenched in a coup cycle? Many of those planning to relocate overseas state that that they do not want to leave the land of their birth, believing it to be the best country in the world, with friendly people, a strong sense of community and a good climate. But they recognize little alternative.

\section{ENDNOTES}

1 This paper deals with the response from the Arya Pratinidhi Sabha of Fiji (APS/Fiji), the Shree Sanatan Dharm Prathinidhi Sabha (SSDPS), The Then India Sanmarga Ikya Sangam (TISI Sangam), Andhra Sangam (AS), Fiji Muslim League (FML), Ahmadiyya Muslim Jama' at (AMJ) and the Indian Division of the Methodist Church. 


\section{The 2006 Military Takeover in Fiji}

2 The RFMF originally went to Qarase's house at $11 \mathrm{am}$, leaving an hour later. At 3pm, approximately 60 soldiers returned to place Qarase under house arrest. Roughly 250 people gathered - some offering prayers and hymns to heal the nation; soldiers awaiting orders while trying to maintain order; bemused spectators watching history unfold; and the media, recording it.

3 Discussions with those assembled revealed the depth of feeling they had for Qarase. By voting for him and his government they claimed that they had endorsed his vision for the future of Fiji. He held their mandate and they gathered to ensure that their voices would be heard and their mandate upheld. ${ }^{4}$ In the weeks after this demonstration, the military were successful in curtailing protest through direct threats and coercion. One notable example was that of the Lami-based democracy rights activists, whose democracy shrine became a source of international media attention and an embarrassment to the military.

5 The 2006 coup was the first to make extensive use of modern technology to transmit information.

Mobile phones were widely used to coordinate group movements, such as the 'Wear Black in Support of Democracy' campaign. Blog sites have also been established within Fiji and overseas. Most of these sites are critical of the military and interim government. Some, such as 'And This Just In' (http://andthisjustin.blogspot.com/) and Fiji Nub News (http://fijinubnews.blogspot.com/), use humour to diffuse the tension; others - Solivakasama (http://solivakasama.wordpress.com/); Intelligensiya http://intelligentsiya.blogspot.com/) and The Rotten State (http://therottenstate.blogspot.com) take a more critical approach.

6 For example, Qarase avoided roadblocks set up to intercept him when returning from a provincial council meeting in Naitasiri by taking a helicopter, landing close to his home, and thereby frustrating the military.

7 In the days after the coup, coup-leader Commodore Bainimarama was characterized as 'ungodly' (Assemblies of God), the 'manifestation of darkness and evil' (Federation of Christian Churches and Assemblies of Christian Churches in Fiji), 'the enemy' (Assemblies of God of Fiji); Qarase was regarded as 'ordained of God' (Assemblies of God), 'doing God's will' (Assemblies of God of Fiji).

${ }^{8}$ Qarase's Methodism is well known, as is Chaudhry's Hindu faith. Indians I have spoken to have expressed a belief that religion is an important component of a just leader.

9 Fiji Bureau of Statistics: Census of Population. 1996.

10 'Standing Up and Together For the Rule of Law', The Fiji Times 4 December 2006.

11 Paid advertisement from the Apostles Gospel Outreach Fellowship International 'Regarding the Current Crisis in Fiji', The Fiji Times, 6 December 2006.

12 Lingat, R. (trans. Derrett, J D M) 1973. The Classical Laws of India, University of California Press, Berkeley. p.4.

13 The term girmit is a corruption of the term 'agreement', referring to the indenture process by which Indians arriving in Fiji signed an agreement committing them to labour for a minimum period of 5 years. This period was characterized by violence, poverty, and social problems (such as adultery, suicide and murder). For further details of this period see: Naidu, V. 2004. The Violence of Indenture in Fiji. Fiji Institute of Applied Studies, Lautoka, and Prasad, R. 2004. Tears in Paradise. Glade Publishers, Auckland. and Lal, B.V. 1983. Girmitiyas: The Origins of the Fiji Indians, Canberra. pp. 43-67.

${ }^{14}$ Under the Agricultural Landlord and Tenant Act 1966 (ALTA), land leases were given for a thirty-year period. These began to expire in the mid 1990s. For further details see Reddy, M. and Naidu, V. 2001. 'Land tenure system in Fiji: the poverty implications of expiring leases', available at: http://devnet.anu.edu.au/online\%20versions\%20pdfs/55/10Reddy55.pdf (accessed November 2007) 152007 saw the Fiji Sugar Corporation (FSC) unable to meet its sugar cane quotas for the European Union; it imported 40,000 tons of sugar from India to meet this obligation. The Fiji Times Online 17 December 2007 http://www.fijitimes.com/storey.aspx?id=76789. Fiji plans to import sugar from India again during the 2008 season. http://news.tradingcharts.com/futures/1/5/108234551.html

16 'More Expected to Leave Our Shores', Fiji Daily Post 16 December 2006:3. Figures based upon estimates by UN Population Fund regional representative Najib Hasifi.

17 Adinkah, M. and Chand, A. 1996. Suicide in Fiji: Report of a National Survey, Department of Sociology, USP, Suva.

18 Norton, R. 1977, 1990. Race and Politics in Fiji. University of Queensland Press, Queensland: p.138. See also 'Fiji Coup Sparks attack on Hindus', Hinduism Today, June 1987.

http://www.hinduismtoday.com/archives/1987/06/index.shtml (accessed November 2007), see also 'Coup Culture at a Micro-Level' The Fiji Times, 9 May 2007:7, in which the incidence of physical attacks and robberies targeted against the Indian community is highlighted. 
19 Crimes against Indian families have also been committed by gangs which have included or been headed by Indians.

20 Conversation with farmers in Vanua Levu, 28 December 2007.

21 'Consider Fijian Loyalties' - PM. Fiji Government online portal 3 June 2005. Accessed November 2007.

22 For further information about these two bills see chapter 2, this volume.

23 Healing Fiji through Restorative Justice: A new way towards reconciliation and justice

http://www.parliament.gov.fj/legislative/bills.aspx?billID=247\&viewtype=reports\&billnav=bill (accessed 15 November 2007).

24 Interview with a senior member of the Methodist Church 21 January 2008; see also Barr, K., Fr 2004. The Church and Fijian Ethnocentrism: An Adventure in Religious History and Sociology, Ecumenical Centre For Research Education and Advocacy, Suva. pp.8-9.

25 'Let Us Pray, Churches Say', The Fiji Times, 29 November 2006.

26 Nandan, Satendra. 2000. Fiji: Paradise in Pieces. Centre for Research in the New Literatures in English, Flinders University, Adelaide, p. 15.

27 Said, A and Funk, N. 'The Role of Faith in Cross-Cultural Conflict Resolution' www.gmu.edu/academic/pcs/ASNC83PCS.htm. (accessed 5 February 2008).

28 The Household Incomes and Expenditure Survey 2002/03 found that, in both urban and rural settings, the incidence of poverty was higher amongst Indo-Fijian families than Fijian Families. Further evidence of this is to be found in Kumar S and Prasad B 'Politics of Race and Poverty in Fiji: A Case of Indo-Fijian Community' www.emeraldinsight.com/0306-8293.htm; and 'Black Christmas for Farmers', Fiji Daily Post 24 December 2006. It must be noted that some sections of the Indian community are amongst the richest groups in Fiji. Some prominent Indian business families, such as Vinod Patel, Tappoo and the Punja families are amongst the richest in Fiji. 'Concluding observations of the Committee on the Elimination of Racial Discrimination: Fiji. 02/06/2003. CERD/C/62/CO/3' - Points 16 and 19.

29 Notably, Australia, New Zealand and the United States took a hard-line stance, failing to recognize the interim government and removing their various aid packages and programs. 'Fiji Military Stages Coup, U.S. Suspends Aid', Reuters Online www.reuters.com (accessed 5 December 2006).

30 'Sabha warns on Hardship', Fiji Sun, 3 December 2006.

31 See 'Black Christmas for Farmers', Fiji Daily Post, 24 December 2006.

32 Fiji Sun 8 December 2006.

33 Fiji Sun 8 December 2006.

34 'Hindu Group Calling on Public To Remain Silent', Fiji Daily Post, 28 December 2006.

35 'Sabha Warns on Hardship', Fiji Sun, 3 December 2006. At a later stage the actions of the military were described by the SSDPS as illegal and unconstitutional: 'Army Security Pleases Hindus', Fiji Sun, 13 December 2006.

36 One must, however, draw a distinction between first and second order harms. If an act prevents harm, this is legitimate. However, any subsequent harm resulting from the first order action, such as hardships affecting farmers resulting from international sanctions, in this instance, the first order act remains legitimate as it was designed with the intention of maintaining dharma.

37 'Coup May Hasten Exodus of Ethnic Indians', IPS/Pacific Media Watch, 22 December 2006, http://www.pmw.c2o.org/2006/fiji5091.html.

38 'Sabha Warns on Hardship' Fiji Sun, 3 December 2006; 'Sabha urges sanction removal' Fiji Sun 8 December 2006; 'Army Security Pleases Hindus' Fiji Sun, 13 December 2006; 'Sabha Prays for Good Year' Fiji Sun, 30 December 2006.

39 Interview with Dorsami Naidu 26 January 2008.

40 Interview with Kamlesh Arya 24 January 2008.

41 Interview with a senior member of the Indian division of the Methodist church. January 2008.

42 'Army Security pleases Hindus: Temple Attacks Decline', Fiji Sun, 13 December 2006:2

43 'Soldiers Get a Treat', Fiji Daily Post, 30 December 2006: 21. It must be added that there were also numerous examples of Fijian families garlanding and providing food for soldiers. I witnessed one such act on Christmas Day 2006, with the family saying they were rewarding those who had put the interest of the nation before their families. 


\section{The 2006 Military Takeover in Fiji}

44 Out of a total of 165,398 valid votes, the FLP won 134,022 (81 per cent), whilst the NFP polled 23,263 (14 per cent) and the National Alliance and SDL parties had a combined Indian Communal vote of 7,000 (4.2 per cent).

45 Khan, Benjamin. 1965. The Concept of Dharma in Valmiki Ramayana, Munshiram Manoharlal Publishers PCT Ltd. Bombay. The metaphor does have its limitations, however, as some of Chaudhry's critics argue that while Rama enjoyed popular support when he returned to his kingdom allowing him to resume power peaceably, Chaudhry's return to power was far from populist and was the result of military intervention.

46 Chaudhry, cited in 'Diwali is an integral part of Hindu culture', Fiji Labour Party website, 2 November 2002, http://www.flp.org.fj/n021102.htm.

47 'Mahendra Chaudhry: Democratic Crusader', BBC Website: http://news.bbc.co.uk/1/hi/world/asia-pacific/842714.stm 20/07/00 (accessed 15 November 2007).

48 'It's Illegal - Chaudhry', Fiji Sun, 6 December 2006:2.

49 Bhagavad-Gita 4.7 and 4.8 .

50 The idea of the Laxman-Rekha is an important one in Fiji, with many Sanatani Hindu families performing a pooja (prayer ritual) around the perimeter of their property to protect their home and family from any misfortune, such as burglary or 'black magic'.

51 Discussion with farmers in Vanua Levu, 28 December 2007.

52 After the scandal broke, websites became the immediate 'court' as to Chaudhry's innocence or guilt. In response to stories published on The Fiji Times website, members of the public were encouraged to leave their own thoughts. Some claimed that he had done nothing wrong, and that it was legitimate for him to fundraise. Critics claimed that he had duped the people of Haryana as they believed the money was for the people of Fiji. These calls were echoed by some who had attended similar fundraising tours of America and Australia in which it was claimed that he had fundraised on behalf of the people of Fiji. Many of the critical comments came from overseas Indo-Fijians and highlighted a division between those 'at home' and those overseas. Those 'at home' were critical of dissenting Indian voices and accused them of having abandoned Fiji after 1987. Because of this they had no right to speak out, as they were safe abroad. This is one of the first notable incidents to highlight the division between Indo-Fijians living inside and outside Fiji.

53 The Fiji Times Online, 17 February 2008.

54 'Chaudhry is Finished: Baba', The Fiji Times Online, 24 February 2008.

55 'It was personalised: Interim A-G', The Fiji Times Online, 12 March 2008.

56 The discussion boards and blogsites became battle sites for supporters and detractors of Chaudhry. Some blogsites referred to him as 'Choro' - meaning thief in Hindi, while others referred to him as 'Chodo', a less polite, vulgar term. The debates on The Fiji Times Online discussion boards became heated at times, with some claiming he was misguided, others that he was right. Many of those posting on discussions were from overseas - especially Indians living in Australia, New Zealand, Canada and America, the preferred destinations for Indians that left after the 1987 and 2000 coups. The blogsites were most likely domestically produced and critical of the interim government.

57 Fiji One National News, Interview with Chaudhry, broadcast at 6pm and 10pm 11 March 2008.

58 Their consultative role was limited to issuing submissions on, for example, the 1997 constitution.

59 This was a common theme repeated in interviews with the SSDPS, APS/Fiji and TISI Sangam.

60 'Secretariat Queries Sangam Stand', The Fiji Times Online, 29 March 2008.

61 'Villagers Told People's Charter Will Be Manifesto of New Governments', One National News Online, 7 April 2008.

62 Prasad, J. 'The role of Hindu and Muslim organizations during the 2006 election' in Fraenkel, J. and Firth, S. 2007, From Election to Coup in Fiji: The 2006 Campaign and its Aftermath, IPS Publications, USP, Suva; Asia Pacific Press, ANU, Canberra; ANU EPress.

63 Kelly, J. D. 1991. A politics of Virtue: Hinduism, sexuality and countercolonial discourse in Fiji, University of Chicago Press, Chicago.

64 Interview with Kamlesh Arya 24 January 2008.

65 'It's for the best: Arya accepts NCBBF invite', fijilive, 6 January 2008.

66 Interview with Kamlesh Arya 24 January 2008.

67 During Anirudh Dewarker's radio call-in show on Radio Fiji (2 February 2008) callers put this point to Arya. While he denied that this was the reason, the suspicion still persists. 
68 'Bad Blood Spills from Cracked Walls', Fiji Sun, 11 March 2006: 7)

69 PM Bainimarama - Address at the Arya Prathinidhi Sabha of Fiji Convention, 2007. Fiji Government Online: http://www.fiji.gov.fj/publish/page_9265.shtml 24/07/07 (accessed 15/11/07).

70 'Sanatan President Admits Differences on NCBBF Decision', One National News Online

ttp://www.fijitv.com.fj/index.cfm?si=main.resources\&cmd=forumview\&uid=newsnational\&cbegin=9541

23 March 2008.

71 'Mandate to speak', The Fiji Times Online, 26 March 2008.

72 'Lack of Participation Hurts Charter, Ratu Joni Says', The Fiji Times, 22 March 2008.

73 The Fiji Times Online voice of the people 7 April 2008.

74 Lal, B.V. 2000. Chalo Jahaji: On a Journey Through Indenture in Fiji. Prashant Pacific, Suva; Division of Pacific and Asian History, Australian National University, Canberra.

75 'Secretariat queries Sangma Stand', The Fiji Times Online, 29 March 2008.

76 'New Members Answer President's Call', Fiji Daily Post, 16 April 2008.

77 Interview with Vinod Naidu 14 June 2006.

78 Shameem, S. 2007. The Assumption of Executive Authority on December $5^{\text {th }} 2006$ by the Commodore $J$. $V$ Bainimarama, Commander of the Republic of Fiji Military Forces: Legal, Constitutional and Human Rights Issues, Fiji Human Rights Commission. Available at www.fijiliv.com_archieve_showpdf.php_pdf=2007_08_FHRC_report_UN_H_Commissioner.pdf (accessed 8 January 2008).

79 Letter: Critique of FML decision to make submission to Constitution Commission A S Khaiyum http://www.fijihosting.com/pcgov/docs_o/askhaiyum_letter.htm

80 'Muslim Community Celebrate Prophet Mohammed's Birthday', One National News Online 17 March 2008.

81 'Muslim League', A Q Buksch. Fiji Daily Post Online, 15 March 2008.

82 'Chand lauds Muslim community', The Fiji Times Online, 17 March 2008.

83 'Ahmadiyya Muslim Jama'at Association Celebrates Prophet Mohammed Day',

One National News Online, 17 March 2008.

84 The Caliph is the senior Ahmadiyya religious leader in Fiji.

85 'Love Thy Country - Munshi', Fiji Government Online, 31 March 2008.

86 Interview with a senior member of the Methodist Church, January 2008. 